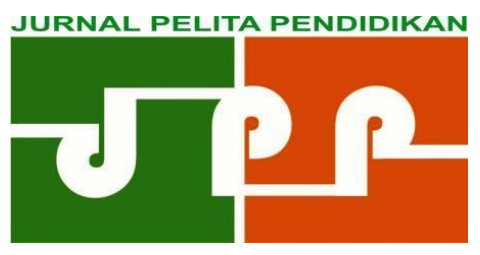

\title{
ANALISIS KETERAMPILAN METAKOGNITIF SISWA PADA PEMBELAJARAN SAINTIFIK MATERI KEANEKARAGAMAN HAYATI
}

\author{
Fanindria Agati ${ }^{1 *}$, Hasruddin $^{1}$, Ikhwan Hasibuan $^{2}$ \\ ${ }^{1}$ Program Studi Pendidikan Biologi, Fakultas Matematika dan Ilmu Pengetahuan Alam, Universitas Negeri \\ Medan, Jalan Willem Iskandar Pasar V Medan Estate 20221, Sumatera Utara, Indonesia \\ ${ }^{2}$ Guru Biologi SMA Negeri 1 Labuhan Deli Jalan Serbaguna Ujung Pasar IV Helvetia, Tanjunggusta, \\ Sunggal, Kabupaten Deli Serdang, Kode Pos 20373. \\ Korespondensi Author: fanindria04@gmail.com (Agati)
}

\section{INFO ARTIKEL}

\section{Histori Artikel}

Received 30 Oktober 2018

Revised 28 Maret 2019

Accepted 22 April 2019

Published 7 Juli 2019

Keywords:

Metacognitive Skills, Scientific Learning, Biodiversity

\begin{abstract}
This research aims know the students' metacognitive skills in scientific learning in class X SMA Negeri 1 Labuhan Deli academic year 2018/2019. The population in this research were all students at class X MIA SMA Negeri 1 Labuhan Deli academic year 2018/2019. The sampel in this research were 1 class (36 students) with taken interpretation technique is random sampling. Data collection techniques were carried out through questionnaires, essay test and observation of sheet to students and interviews with teacher of biology studies. The results of data analysis obtained were the percentage of student's metacognitive skills from question results $72 \%$ in the high criteria. The results of essay test $55.6 \%$ (55\%) in the medium criteria. The average percentage of scientific learning observations is $57 \%$ in the medium criteria. From the results of data analysis obtained the value of $r=0.83$ by testing the hypothesis using the test with results $\mathrm{t}$ count $>\mathrm{t}$ table $=12.9>2.028$ which mean $\mathrm{HO}$ is rejected and $\mathrm{Ha}$ is accepted. It can be there is a positive relations between metacognitive skilss and scientific learning.
\end{abstract}

How to Cite:

Agati, F., Hasruddin, Hasibuan, I. (2019). Analisis Keterampilan Metakognitif Siswa Pada Pembelajaran Saintifik Materi Keanekaragaman Hayati. Jurnal Pelita Pendidikan, 7(1), 049-054.

\section{PENDAHULUAN}

Keterampilan metakognitif diperlukan
untuk kesuksesan belajar karena dengan
keterampilan metakognitif memungkinkan siswa
mampu mengelola kecakapan kognitif atau
pengetahuannya dan mampu melihat kelemahannya
sehingga dapat dilakukan perbaikan pada tindakan-

tindakan berikutnya. Lebih lanjut, dinyatakan bahwa siswa yang mampu menggunakan keterampilan metakognitifnya akan memiliki prestasi yang lebih baik dibandingkan dengan siswa yang tidak menggunakan keterampilan metakognitifnya. Hal ini disebabkan karena keterampilan metakognitif dapat memungkinkan siswa melakukan perencanaan, 
mengikuti perkembangan, dan memantau proses belajarnya (Eriawati, 2013).

Kemampuan metakognisi dan prestasi akademik memiliki hubungan positif yang dapat diberdayakan. Kenyataan dalam pembelajaran biologi yang dilakukan selama ini semata-mata hanya menekankan pada penguasaan konsep kognitif yang didapatkan dengan tes tertulis objektif, sedangkan ruang untuk metakognisi kurang diberdayakan. Kegiatan belajar seperti ini membuat siswa cenderung belajar mengingat atau menghafal juga tanpa memahami atau tanpa mengerti apa yang diajarkan oleh gurunya. Akibatnya ketika siswa dihadapkan dengan masalah, siswa mengalami kesulitan untuk memecahkannya (Pratiwi, 2016).

Beberapa penelitian menemukan bahwa kemampuan metakognitif siswa (kesadaran dan keterampilan metakognitif), berada pada level cannot really (tidak mampu memisahkan apa yang dipikirkan dan bagaimana ia berpikir) dan at risk (siswa tampak tidak memiliki kesadaran berpikir sebagai suatu proses). Kondisi ini menunjukkan bahwa siswa mengalami kesulitan dalam mengukur dan mengatur perkembangan berpikirnya. Hal ini sangat disayangkan, karena keterampilan metakognitif dapat mendorong perkembangan kognitif siswa. Keterampilan metakognitif merupakan strategi sederhana, namun sangat kuat untuk meningkatkan daya pikir siswa dan kemampuan belajarnya. Lebih lanjut, kurangnya pengembangan keterampilan metakognitif dikhawatirkan dapat mengakibatkan rendahnya kualitas pendidikan yang ada di Indonesia (Setiawan \& Herawati 2013).

Proses pembelajaran merupakan proses interaksi antar peserta didik dan antar peserta didik dengan pendidik dan sumber belajar pada suatu lingkungan belajar. Proses pembelajaran demikian akan bermakna jika pembelajarannya berbasis keilmuan. Pembelajaran sains seyogyanya lebih menekankan pada proses, siswa aktif selama pembelajaran untuk membangun pengetahuannya melalui serangkaian kegiatan agar pembelajaran menjadi bermakna bagi siswa. Pada prinsipnya keterampilan dasar dan keterampilan terintegrasi memiliki kesamaan dalam hal merumuskan permasalahan, mengumpulkan data dan mengajukan solusi pemecahan masalah (Iskandar, 2014).

Pembelajaran saintifik merupakan pembelajaran yang memberikan pengalaman belajar dengan urutan logis meliputi proses pembelajaran mengamati, menanya, mengumpulkan berbagai informasi/mencoba, menalar/mengasosiasi, dan mengomunikasikan. Langkah logis ini sangat strategis untuk mengatur proses berpikir siswa. Fenomena pembelajaran biologi yang belum memberdayakan keterampilan metakognisi diduga masih terjadi dan dialami oleh para siswa ,Permasalahan ini dimungkinkan, karena sebagian guru IPA biologi belum memahami benar konsep dan pentingnya melatih keterampilan dan metakognisi bagi siswa. Akibatnya, proses pembelajaran cenderung kurang bermakna (Mamu, 2014).

\section{METODE PENELITIAN}

Metode penelitian ini dilakukan secara deskriptif survei. Populasi penelitian ini adalah seluruh siswa kelas X MIA SMA Negeri 1 Labuhan Deli T.P 2018/2019 dengan jumlah 138 siswa dan yang menjadi sampel sebanyak 1 kelas berjumlah 36 siswa. Pengambilan sampel dengan cara random sampling yaitu pengambilan anggota sampel dari populasi dilakukan secara acak tanpa memperhatikan strata yang ada dipopulasi itu. Instrumen Penelitian adalah angket, essay test dan lembar observasi. Teknik analisis data angket dalam penelitian ini menggunakan teknik deskriptif kuantitatif dengan perhitungan persentase.

\section{HASIL DAN PEMBAHASAN}

Berdasarkan data yang diperoleh dari hasil jawaban siswa pada angket keterampilan metakognitif materi keanekaragaman hayati diperoleh skor tertinggi yaitu 87 dan skor terendah yaitu 60 dengan rata - rata $(\bar{X})=72$ diketahui bahwa 36 siswa yang menjadi responden angket keterampilan metakognitif semuanya berada pada kriteria tinggi. Dengan demikian, persentase keterampilan metakognitif berdasarkan angket adalah pada kategori tinggi dengan jumlah responden sebanyak 36 orang siswa (100\%). 
Sehingga persentase keterampilan metakognitif berdasarkan hasil angket kelas X MIA SMA Negeri 1 Labuhan Deli T.P 2018/2019 berada pada kriteria tinggi.

Berdasarkan data yang diperoleh dari hasil jawaban siswa terhadap Essay test keterampilan metakognitif materi keanekaragaman hayati dengan jumlah responden 36 siswa diperoleh skor tertinggi yaitu 73 dan skor terendah yaitu 46 dengan rata rata $(\bar{X})=59.5$. Diketahui bahwa tidak terdapat siswa yang memiliki keterampilan metakognitif sangat tinggi, 5 orang siswa memiliki keterampilan metakognitif kategori tinggi (13.9\%), 31 orang siswa memiliki keterampilan metakognitif kategori sedang (86.1\%), dan tidak ada siswa yang memiliki keterampilan metakognitif rendah dan sangat rendah. Dengan demikian, persentase tertinggi keterampilan metakognitif berdasarkan essay test berada pada kategori sedang dengan jumlah responden sebanyak 31 orang siswa (86.1\%). Sehingga persentase keterampilan metakognitif berdasarkan hasil essay test berada pada kategori sedang, disajikan pada Gambar 1 berikut.

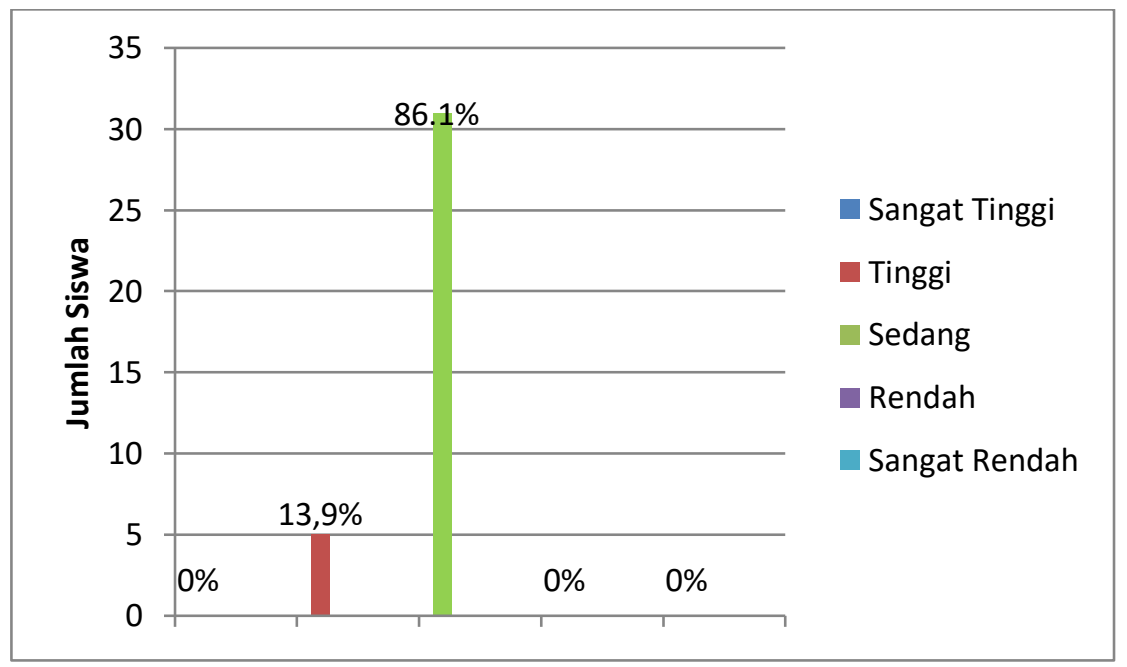

Gambar. 1 Grafik Perbandingan Tingkat Keterampilan Metakognitif Siswa Berdasarkan Hasil Essay Test

Pada pembelajaran saintifik persentase perorangan dan persentase rata-rata kegiatan $5 \mathrm{M}$ siswa pada materi keanekaragaman hayati di kelas $\mathrm{X}$ SMA Negeri 1 Labuhan Deli dengan jumlah responden 36 siswa diperoleh skor tertinggi yaitu 101 dan skor terendah yaitu 61 dengan rata - rata $(\bar{X})=81$. Diketahui bahwa terdapat 2 orang siswa $(5,6 \%)$ yang memiliki hasil observasi pembelajaran saintifiknya tinggi, 34 orang siswa hasil observasi pembelajaran saintifiknya berada kategori sedang
(94,4\%), dan tidak ada siswa yang memperoleh persentase pada kategori sangat tinggi, rendah, dan sangat rendah. Dengan demikian, persentase tertinggi pembelajaran saintifik berdasarkan hasi observasi berada pada kategori sedang dengan jumlah responden sebanyak 34 orang siswa $(94,4 \%)$. Sehingga skor berdasarkan hasil observasi di kelas $X$ MIA SMA Negeri 1 Labuhan Deli T.P 2018/2019 cenderung sedang. 


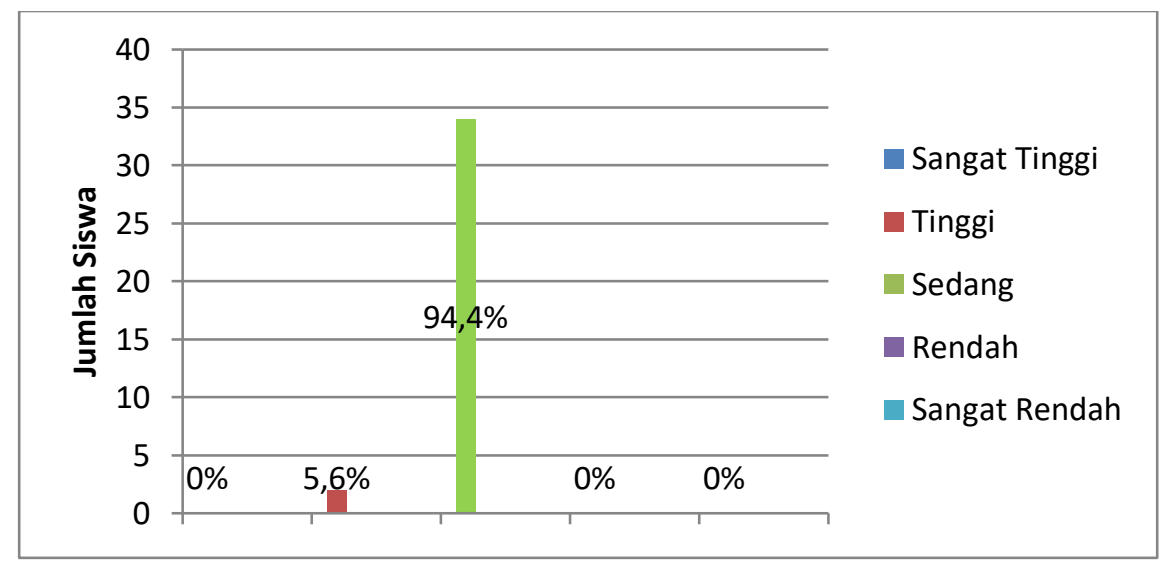

Gambar 1. Grafik Perbandingan Tingkat Pembelajaran Saintifik Siswa Berdasarkan Hasil Observasi.

Dari hasil perhitungan pembelajaran saintifik dengan menggunakan lembar observasi didapatkan hasil data kegiatan $5 \mathrm{M}$ yang disajikan dalam bentuk Tabel 1 berikut.

Tabel 1. Persentase Kegiatan 5M

\begin{tabular}{clcc}
\hline No & Kegiatan 5M & Persentase & Kategori \\
\hline 1. & Mengamati & $62 \%$ & Sedang \\
2. & Menanya & $58 \%$ & Sedang \\
3. & Mengumpulkan data & $58 \%$ & Sedang \\
4. & Mengasosiasi/Menalar & $56 \%$ & Sedang \\
5. & Mengkomunikasikan & $56 \%$ & Sedang \\
\hline
\end{tabular}

Data uji korelasi dengan mencari nilai $r$ menunjukkan adanya saling berhubungan atau saling terkait antara keterampilan metakognitif dengan pembelajaran saintifik. Perolehan nilai $r$ adalah sebesar 0,83 yang artinya interpretasi koefisisen korelasinya tinggi dimana artinya semakin baik penerapan pembelajaran saintifik di suatu sekolah maka semakin tinggi keterampilan metakognitif siswa. Dari daftar distribusi $t$, harga $t t_{a b e l}=2,03224$ pada $p=0,05$ sehingga ternyata $t$ hitumg $>t$ tabel yaitu $15,61>2,03224$. Berdasarkan hasil pengujian maka Ho ditolak dan Ha diterima. Kesimpulan, terdapat hubungan positif antara keterampilan metakognitif dengan pembelajaran saintifik.

Dari hasil perhitungan angket diketahui bahwa keterampilan metakognitif siswa kelas X MIA SMA Negeri 1 Labuhan Deli berada pada kategori tinggi, ini terlihat dari hasil perhitungan data ada sebanyak 36 siswa yang memperoleh persentase dikriteria tinggi, dan tidak ada siswa pada kategori rendah. Hasil perolehan keterampilan metakognitif tertinggi sebesar $87 \%$ dan yang terendah sebesar
60\%. Hasil perhitungan komponen keterampilan metakognitif pada angket, persentase yang paling tinggi terdapat pada komponen perencanaan (planning) sebesar $78 \%$ ini menunjukkan bahwa keterampilan metakognitif siswa pada saat melakukan perencanaan baik yang terdiri dari indikator merumuskan tujuan belajar yang ingin dicapai dan penggunaan alokasi waktu dan sumber belajar. Ini sama halnya dengan komponen pengawasan diri yang berada pada kriteria tinggi diperoleh persentase sebesar $73 \%$ dengan indikator pemantauan tujuan belajar, pemantauan relevansi pengetahuan awal dengan materi serta pemantauan waktu belajar yang digunakan, sedangkan pada komponen manajemen informasi, pemahaman strategi dan evaluasi ketiganya berada pada kriteria tinggi artinya ketika proses pembelajaran siswa dalam manajemen informasi pemahaman strategi belajar, dan evaluasi berdasarkan hasil angket baik.

Keterampilan metakognitif siswa dari hasil Essay Test hanya terdapat 2 siswa yang keterampilan metakognitifnya berada pada kriteria tinggi 
sedangkan 34 siswa lainnya berada pada kategori sedang, dan tidak ada siswa yang memperoleh hasil pada kategori sangat tinggi, rendah, dan sangat rendah. Perolehan persentase hasil Essay Test lebih buruk dibandingkan tes angket dikarenakan pada Essay Test kemampuan keterampilan metakognitif siswa benar-benar diuji dengan menjawab soal yang bersifat analisis, sintesis, dan evaluasi. Sehingga perolehan persentase tertinggi sebesar $74 \%$ dan terendah adalah $46 \%$, tetapi dari data persentase jika dirata-ratakan keseluruhan keterampilan metakognitif siswa berdasarkan hasil Essay Test berada pada kriteria sedang dengan perolehan persentase $56,6 \%$. Hal ini juga diperkuat lagi dengan pernyataan Iskandar (2014) yang menyatakan bahwa unsur analisis, sintesis, dan evaluasi sebagai cikal bakal tumbuh kembangnya kemampuan inkuiri dan kreativitas harus dikembangkan dengan pelaksanaan pembelajaran yang semestinya membiasakan siswa untuk melatih kemampuan metakognitif dengan tidak hanya berpikir sepintas dengan makna yang dangkal.

Pada hasil observasi pembelajaran saintifik diperoleh data pada indikator mengamati sebesar $62 \%$ dimana deskriptor yang paling rendah diperoleh adalah tidak terpengaruh oleh situasi di luar kelas dan mencatat bagian penting, pada deskriptor ini masih banyak siswa yang terkadang masih terpengaruh dengan situasi di luar kelas dan saat pelajaran berlangsung mereka jarang sekali menggunakan catatan untuk mencatat hal-hal penting. Pada deskriptor memperhatikan media dengan seksama diperoleh persentase sebesar $72 \%$, kemudian sesuai hasil wawancara dengan salah satu guru biologi di SMA Negeri 1 Labuhan Deli menyatakan bahwa proses pembelajaran jarang menggunakan proyektor untuk menunjukkan media pembelajaran karena kurangnya ketersediaan fasilitas proyektor di sekolah. Guru ketika proses pembelajaran lebih sering menggunakan media langsung dari alam. Kemudian pada deskriptor fokus saat menerima pelajaran yang sering terjadi ketika proses pembelajaran siswa hanya sering fokus di awal-awal pembelajaran.

Pada indikator menanya diperoleh persentase rata-rata sebesar $58 \%$ ini menunjukkan ketika proses pembelajaran hanya ada beberapa siswa yang sering bertanya kepada guru pelajaran ketika proses pembelajaran berlangsung dan ketika berdiskusi hanya ada sebagian kecil siswa yang melakukan interupsi.

Pada indikator mengumpulkan data/ eksperimen diperoleh persentase sebesar $58 \%$ dengan kriteria sedang. Ketika melakukan proses pembelajaran sesuai dengan hasil wawancara guru biologi SMA Negeri 1 Labuhan Deli siswa diberi tugas untuk memperhatikan lingkungan sekitar sekolah untuk memperoleh data sebagai sumber pengetahuan terhadap materi keanekaragaman hayati namun pada saat diminta untuk melakukan pengecekan informasi masih banyak siswa yang kurang tepat dalam menentukan kebenaran informasi tersebut dan keaktifan siswa untuk melakukan tanya jawab dengan guru pengajar atau guru lain masih kurang, namun ketika siswa diminta untuk melakukan pencarian data dan informasi dari sumber lain seperti internet mereka sedang antusias sehingga dapat digolongkan pada kriteria sedang atau sedang.

Pada indikator mengasosiasi/ menalar diperoleh persentase sebesar 56\% dengan kriteria rendah ini disebabkan karena pada saat menganalisis data dalam bentuk informasi dan menghubungkan informasi-infornasi terkait siswa-siswi kelas X SMA Negeri 1 Labuhan Deli masih kurang tanggap, sehingga ketika mencoba menyusun jawaban atau menyimpulkan jawaban juga masih rendah.

Pada indikator mengkomunikasikan diperoleh persentase rata-rata sebesar $56 \%$ berada pada kriteria sedang ini dikarenakan masih banyak siswa yang ketika menyajikan laporan dalam bentuk grafik, gambar, karya ilmiah secara sistematis dan lengkap yang meliputi proses, hasil, dan kesimpulan secara lisan maupun tulisan masih rendah. Dari data diatas diketahui bahwa persentase rata-rata keseluruhan pembelajaran saintifik berada pada kriteria sedang dengan hasil persentase sebesar $56 \%$. Hasil perolehan persentase yang didapat termasuk nilai kategori sedang dalam hal ini sebaiknya untuk penerapan pembelajaran saintifik diperlukan kefahaman dan kreativitas guru dalam 
menyampaikan materi dengan pendekatan ilmiah (Sumayasa, 2015).

Berdasarkan hasil perhitungan data korelasi diketahui bahwa terdapat hubungan yang positif antara keterampilan metakognitif dengan pembelajaran saintifik yang berkorelasi tinggi. Hal ini diperkuat dengan hasil penelitian Kristiani (2015) yang menyatakan bahwa ada hubungan positif antara keterampilan metakognitif dengan pembelajaran saintifik, dan hasil penelitian ini menunjukkan bahwa keterampilan metakognitif sangat berpengaruh terhadap hasil belajar kognitif pada pembelajaran saintifik. Hal ini membuktikan bahwa melatih keterampilan metakognitif dapat menyadarkan siswa untuk belajar, merencanakan belajarnya, mengontrol proses belajarnya, dan mengevaluasi kemampuannya sebagai pelajar.

Metakognisi memegang salah satu peranan sangat penting agar pembelajaran berhasil. Oleh karena itu keterampilan metakognitif diperlukan siswa untuk mengatur strategi yang efektif untuk belajar agar mereka terhindar dari ketidakmampuan dalam belajar. Metakognisi penting dalam pembelajaran dan merupakan prediktor kuat dari keberhasilan academis (Dunning et al,2003). Siswa dengan metakognisi yang baik menunjukkan prestasi akademis yang baik dibandingkan dengan siswa yang rendah metakognisinya. Dengan demikian, metakognisi berhubungan dengan keberhasilan akademik siswa sehingga penting diberdayakan melalaui pembelajaran saintifik.

\section{KESIMPULAN}

Sebagai kesimpulan keterampilan metakognitif siswa pada materi keanekaragaman hayati berada pada kriteria tinggi (berdasarkan angket) dan persentase rata-rata berdasarkan hasil essay test berada pada kriteria sedang. Hasil observasi pembelajaran saintifik terhadap siswa pada materi keanekaragaman hayati berada pada kriteria sedang. Proses pembelajaran saintifik siswa masih kurang baik ketika proses pembelajaran berlangsung. Terdapat hubungan positif antara keterampilan metakognitif dengan pembelajaran saintifik di SMA Negeri 1 Labuhan Deli.

\section{DAFTAR PUSTAKA}

Dunning D., Johnson, K., Ehrlinger,J. 2003. Why People Fail to Recognize ther Own Incompentence. Current Direction in Physicological Science 12 (3): 83-87

Eriawati. 2013. Aplikasi Keterampilan Metakognitif dalam Pembelajaran Ekosistem di MAN Rukoh Jurnal Biotik. 1 (1): 60-66.

Mamu, H. D. 2014. Profil Keterampilan Berpikir Kritis dan Metakognisi Siswa dalam Pembelajaran IPA Biologi di SMP.Jurnal Untad.ac.id.17 (3): 38-48.

Iskandar, S. M. 2014. Pendekatan Keterampilan Metakognitif dalam Pembelajaran Sains di Kelas. Jurnal Erudio. 2 (2): 12-20.

Kristiani, N. 2015. Hubungan Keterampilan Metakognitif dan Hasil Belajar Kognitif Siswa pada Pembelajaran Saintifik dalam Mata Pelajaran Biologi SMA Kurikulum 2013. Jurnal Seminar Nasional, Malang: UNS.

Pratiwi, dkk. 2016. Peningkatan Kemampuan Metakognisi dengan Hasil belajar Siswa dengan Pendekatan Keterampilan Proses Melalui Think Pair Share pada Siswa kelas X-3 SMAN Yosowilangun Lumajang Tahun 2014/2015. Jurnal Edukasi UNEJ. III (2): 22-28.

Setiawan, D \& Herawati, S. 2015. Peningkatan Keterampilan Metakognitif Mahasiswa Program Studi Biologi Melalui Penerapan Jurnal Belajar dengan Strategi Jigsaw dipadu PBL Berbasis Lesson Study pada Mata kuliah Biologi Umum. Malang; Universitas Muhammadiyah Malang.

Sumayasa, I.Y. 2015. Pengaruh Implementasi Pendekatan Scientific Approach Terhadap Motivasi Belajar dan Hasil Belajar pada Siswa Kelas VI di Sekolah Dasar Segugur VI Kecamatan Abang, Karangasem. E. Jurnal Program Pascasarjana Universitas Pendidikan Ganesha Program Studi Pendidikan Dasar. 5 (1): 1-13. 